Article

\title{
Oxide-Inclusion Evolution in the Steelmaking Process of 304L Stainless Steel for Nuclear Power
}

\author{
Xingrun Chen ${ }^{1,2}$, Guoguang Cheng ${ }^{1, *}$, Yuyang Hou ${ }^{1}$ and Jingyu Li ${ }^{1}$ \\ 1 State Key Laboratory of Advanced Metallurgy, University of Science and Technology Beijing, \\ Beijing 10083, China; chenxingrun@jiugang.com (X.C.); hyyustb@gmail.com (Y.H.); \\ b20160493@xs.ustb.edu.cn (J.L.) \\ 2 Hongxing Iron \& Steel Co. Ltd., Jiuquan Iron and Steel Group Corporation, Jiayuguan 735100, Gansu, China \\ * Correspondence: chengguoguang@metall.ustb.edu.cn; Tel.: +861062334664
}

Received: 6 January 2019; Accepted: 18 February 2019; Published: 21 February 2019

check for updates

\begin{abstract}
The inclusions formed in 304L stainless steel for nuclear power produced by the electric arc furnace (EAF)-argon oxygen decarburization furnace (AOD)-ladle furnace (LF)-continuous casting (CC) process were investigated by thermodynamics calculations and experimental results. The results showed that the inclusions after AOD and LF refining were almost the same as the slag composition. The types of inclusions (sizes larger than $5 \mu \mathrm{m}$ ) were mainly $\mathrm{CaSiO}_{3}$ with high $\mathrm{SiO}_{2}$ content at the end of $\mathrm{AOD}$, and $\mathrm{Ca}_{2} \mathrm{SiO}_{4}$ with high $\mathrm{CaO}$ content at the end of $\mathrm{LF}$. The $\mathrm{Al}_{2} \mathrm{O}_{3}$ and $\mathrm{MgO}$ content of inclusions increased from AOD to LF. There were two types of inclusions in the tundish: $\mathrm{CaO}-\mathrm{SiO}_{2}-\mathrm{Al}_{2} \mathrm{O}_{3}-\mathrm{MgO}$ and $\mathrm{CaO}-\mathrm{SiO}_{2}-\mathrm{Al}_{2} \mathrm{O}_{3}-\mathrm{MgO}-\mathrm{MnO}$ inclusions with $\mathrm{MgO} \cdot \mathrm{Al}_{2} \mathrm{O}_{3}$ spinel precipitation. The content of $\mathrm{Al}_{2} \mathrm{O}_{3}$ in the inclusions increased rapidly with the decrease in temperature from the end of LF refining to continuous casting, as calculated using FactSage6.3 software. The rapid increase of $\mathrm{Al}_{2} \mathrm{O}_{3}$ in the $\mathrm{CaO}-\mathrm{SiO}_{2}-\mathrm{Al}_{2} \mathrm{O}_{3}-\mathrm{MgO}-(\mathrm{MnO})$ inclusions promoted the precipitation of $\mathrm{MgO} \cdot \mathrm{Al}_{2} \mathrm{O}_{3}$ spinel in continuous casting tundish, suggesting mechanisms for the formation of inclusions in the 304L stainless steel.
\end{abstract}

Keywords: 304L stainless steel for nuclear power; oxide-inclusion evolution; $\mathrm{MgO} \cdot \mathrm{Al}_{2} \mathrm{O}_{3}$ spinel; precipitation

\section{Introduction}

With good corrosion resistance, favorable mechanical properties, and excellent cold and hot processing properties, austenitic stainless steel is used in the petroleum, chemical, aerospace, and nuclear industries [1,2]. As a typical austenitic stainless steel, 304L stainless steel is widely used in harsh environments, including nuclear power plants and storage and transportation containers for cryogenic liquid [3-7]. For safe use in these harsh application environments, the purity and content of carbon and nitrogen, and the impurity elements of 304L austenitic stainless steel must be strictly controlled. Non-metallic inclusions in 304L stainless steel must be removed if it is to be used for nuclear power applications, since the presence of these inclusions can cause deterioration of mechanical properties, promote surface defects, and serve as initiation sites for corrosion-fatigue cracks, potentially leading to operational complications [8-11]. Therefore, the effective control of non-metallic inclusions is very important for the production of 304L stainless steels for nuclear power applications.

The evolution mechanism of inclusions in austenitic stainless steel has been widely studied [12-20]. Inclusion evolution during refining and continuous casting of 316L stainless steel was described by Yin et al. [15]. The authors reported precipitation of harmful crystals of $\mathrm{MgO} / \mathrm{Al}_{2} \mathrm{O}_{3}$ spinel within the steel melt and within the calcium silicate matrix of existing inclusions occurred as the temperature decreased from the tundish until solidification. The compositional evolution of oxide inclusions in 
austenitic stainless steel during continuous casting was reported by Choi et al. [16]. The authors found that the basicity $\left(\% \mathrm{CaO} / \% \mathrm{SiO}_{2}\right)$ of the inclusions decreased with decreasing inclusion size, and the manganese oxide content (\%MnO) increased as inclusion size decreased. Park and Todoroki [17] reported that for $\mathrm{Si}$ deoxidation, most actions resulted in the formation of silicate type inclusions with lower melting temperatures. Lowering $\mathrm{MgO}$ and $\mathrm{Al}_{2} \mathrm{O}_{3}$ in the slag helped to eliminate the most influential oxides. Yan et al. [18] found that in the slag-steel-inclusions reaction system, the top slag-steel reaction affected the molten steel chemistry, consequently influencing the compositional evolution of inclusions during the ladle treatment. Similar results were presented by Ren et al. [19], who found that a low basicity slag resulted in lower $[\mathrm{Al}]_{\mathrm{s}}$ in stainless steel, which helped to avoid the formation of $\mathrm{Al}_{2} \mathrm{O}_{3}$-rich inclusions and improve the deformability of inclusions.

However, the oxide-inclusion evolution of 304L stainless steel produced for nuclear power applications remains poorly understood. Although previous investigations have described the crystallization behavior of the spinel phase during the stainless steelmaking process, there has been no comprehensive study of the evolution of inclusions, including their detailed characteristics, and no examination of the thermodynamic parameters of the formation mechanism of spinel inclusions in 304L stainless steel for nuclear power. In this study, the inclusions in 304L stainless steel produced by a 100ton electric arc furnace(EAF)-110 ton argon oxygen decarburization furnace (AOD)-110 ton ladle furnace (LF)-continuous casting (CC) process were systematically investigated by microanalysis and thermodynamic analysis.

\section{Experiments}

\subsection{Experimental Procedure and Sampling}

In this work, 304L stainless steel materials were produced by the EAF-AOD-LF-CC process. First, waste steel, nickel iron, and ferrochrome were melted in an electric arc furnace, and then poured into the AOD converter. After decarburization in the AOD converter, ferrosilicon was added for reduction when the content of carbon reached the target value, allowing the desulphurization process after reduction. The aluminum content of the ferrosilicon was $1.3 \%$. After completion of the AOD process, the liquid steel was transferred to LF (the refractory material is magnesia-calcium) for refining. Lime and fluorite were added for secondary refining, with a target value of basicity of 2.20. When the composition and temperature reached the target value, the molten steel was transported to the continuous casting platform for casting. The main component of tundish fluxes was $85 \mathrm{wt} \% \mathrm{MgO}$, $1.27 \mathrm{wt} \% \mathrm{CaO}, 2.65 \mathrm{wt} \% \mathrm{SiO}_{2}, 0.01 \mathrm{wt} \% \mathrm{Al}_{2} \mathrm{O}_{3}$, and $0.59 \mathrm{wt} \% \mathrm{C}$.

Separate steel samples were removed after the AOD treatment, LF refining, and casting process, and the inclusions were analyzed. Additionally, slag samples were removed after AOD treatment and LF refining. The composition of the molten steel, composition of the slag, and size and composition of the inclusions were measured and the results were presented as the mean values of measurements from 18 samples.

\subsection{Analysis of Samples}

The steel samples $(\Phi 30 \mathrm{~mm} \times 10 \mathrm{~mm}$ ) were cleaned by machining the surface before chemical analysis. The chemical composition of the steel samples was determined by the direct reading spectrum (ARL4460, Thermo Fisher Scientific, MA, USA). Cylinders $(\Phi 5 \mathrm{~mm} \times 5 \mathrm{~mm}$ ) were machined to measure the $\mathrm{C}, \mathrm{S}, \mathrm{O}$ and $\mathrm{N}$ contents. The contents of $\mathrm{C}$ and $\mathrm{S}$ were analyzed by a $\mathrm{C} / \mathrm{S}$ analyzer (CS-800, ELTRA, Haan, Germany). The contents of $\mathrm{O}$ and $\mathrm{N}$ were analyzed by an $\mathrm{O} / \mathrm{N}$ analyzer (EMGA-620W, Horiba, Kyoto, Japan). The $\mathrm{Al}$ and $\mathrm{Ca}$ contents in the steel were determined by inductively coupled plasma-optical emission spectroscopy (ICP-OES). The composition of $5 \mathrm{~g}$ slag samples was analyzed using an X-ray fluorescence spectrometer (ARL PERFORM'X, Thermo Fisher Scientific, MA, USA).

The $15 \mathrm{~mm} \times 15 \mathrm{~mm} \times 10 \mathrm{~mm}$ samples for scanning electron microscopy (SEM; Merlin Compact, Zeiss, Gottingen, Germany) were made by cutting, grinding and polishing. The morphology and 
composition of nonmetallic inclusions of the steel specimens were analyzed by SEM with an energy dispersive spectrometer (EDS; X-Max 80, Oxford Instruments, High Wycombe, UK). The element maps of inclusions were analyzed by electron probe microanalysis (JXA8230, JEOL, Tokyo, Japan) (EPMA) with wavelength dispersive spectrometer (WDS). Inclusions smaller than $5 \mu \mathrm{m}$ did not affect the properties of the steel. Additionally, the interaction volume could spread into the steel and excite electrons from the surrounding environment for inclusions smaller than $5 \mu \mathrm{m}$. Therefore, for more accurate analysis of inclusions, only inclusions larger than $5 \mu \mathrm{m}$ in size were studied.

\section{Results}

\subsection{Composition of the Molten Steel and Slag}

The average chemical compositions of molten steel and slag at various stages were determined and are listed in Tables 1 and 2, respectively. The binary basicity $\left(\mathrm{CaO} / \mathrm{SiO}_{2}\right)$ of AOD slag is 1.85, whereas that of LF slag is 2.20. The levels of $\mathrm{Cr}_{2} \mathrm{O}_{3}$ and $\mathrm{FeO}$ in slag after LF refining were much lower than those after AOD treatment. The total oxygen (T.O) content decreased during the steelmaking process. The levels of $\mathrm{Mg}$ and $\mathrm{Al}$ increased in the steel from the AOD to LF stages and the $\mathrm{MgO}$ and $\mathrm{Al}_{2} \mathrm{O}_{3}$ content also increased in the slag.

Table 1. Chemical composition of 304L at different stages (mass fraction \%).

\begin{tabular}{cccccccccc}
\hline Stage & $\mathbf{C}$ & $\mathbf{S i}$ & $\mathbf{M n}$ & $\mathbf{N i}$ & $\mathbf{C r}$ & $\mathbf{A l}$ & $\mathbf{M g}$ & $\mathbf{C a}$ & T.O \\
\hline After AOD & 0.011 & 0.14 & 1.50 & 8.12 & 17.99 & 0.003 & 0.0006 & 0.0011 & 0.0152 \\
After LF & 0.015 & 0.37 & 1.59 & 8.21 & 18.14 & 0.004 & 0.0008 & 0.0006 & 0.0047 \\
Tundish & 0.015 & 0.38 & 1.58 & 8.27 & 18.10 & 0.004 & 0.0008 & 0.0006 & 0.0040 \\
\hline
\end{tabular}

Table 2. Chemical composition of 304L slag at different stages (mass fraction \%).

\begin{tabular}{ccccccc}
\hline Stage & $\mathbf{C a O}$ & $\mathbf{S i O}_{\mathbf{2}}$ & $\mathbf{M g O}$ & $\mathbf{A l}_{\mathbf{2}} \mathbf{O}_{\mathbf{3}}$ & $\mathbf{C r}_{\mathbf{2}} \mathbf{O}_{\mathbf{3}}$ & $\mathbf{F e O}$ \\
\hline After AOD & 55.97 & 30.21 & 4.47 & 1.37 & 1.49 & 2.36 \\
After LF & 58.69 & 26.63 & 6.08 & 1.89 & 0.07 & 0.13 \\
\hline
\end{tabular}

\subsection{Type of Inclusions in the Smelting Process}

Nearly 20 inclusions were selected for characterization with samples taken at different stages. The morphology of the inclusions in molten steel during the AOD-LF-CC process was characterized, as shown in Figure 1. WDS element maps of typical $\mathrm{CaO}-\mathrm{SiO}_{2}-\mathrm{Al}_{2} \mathrm{O}_{3}-\mathrm{MgO}$ inclusions in molten steel during the AOD-LF-CC process are shown in Figure 2. The main inclusion was spherical $\mathrm{CaO}-\mathrm{SiO}_{2}-\mathrm{Al}_{2} \mathrm{O}_{3}-\mathrm{MgO}$, with the size ranging from several to tens of microns at the end of $\mathrm{AOD}$ smelting (Figure 1a). These inclusions contained a small amount of magnesium and aluminum (Figure 2a). At the end of LF, the types of inclusions less than $20 \mu \mathrm{m}$ in size were essentially the same as that of AOD, as shown in Figure 1b. WDS element maps of typical homogeneous $\mathrm{CaO}-\mathrm{SiO}_{2}-\mathrm{Al}_{2} \mathrm{O}_{3}-\mathrm{MgO}$ inclusions are shown in Figure $2 \mathrm{~b}$. In Figure $1 \mathrm{c}$, in addition to the spherical $\mathrm{CaO}-\mathrm{SiO}_{2}-\mathrm{Al}_{2} \mathrm{O}_{3}-\mathrm{MgO}$, there were $\mathrm{CaO}-\mathrm{SiO}_{2}-\mathrm{Al}_{2} \mathrm{O}_{3}-\mathrm{MgO}-\mathrm{MnO}$ inclusions in continuous casting tundish, with an average size less than $10 \mu \mathrm{m}$. WDS element maps of typical inclusions are shown in Figure 2c. The results indicated that the spinel phase can be crystallized in the $\mathrm{CaO}-\mathrm{SiO}_{2}-\mathrm{Al}_{2} \mathrm{O}_{3}-\mathrm{MgO}-\mathrm{MnO}$ and $\mathrm{CaO}-\mathrm{SiO}_{2}-\mathrm{Al}_{2} \mathrm{O}_{3}-\mathrm{MgO}$ inclusions in the tundish. 


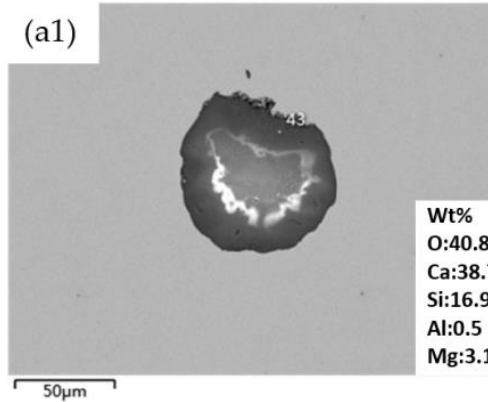

(a2)

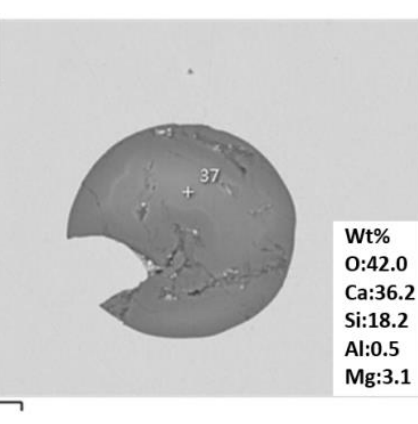

(a3)

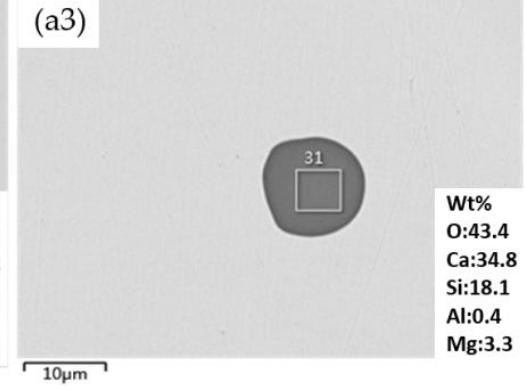

(b1)

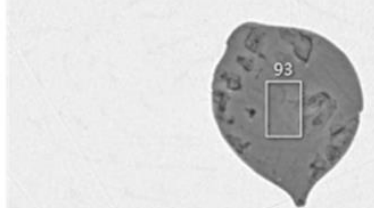

$\longdiv { 1 0 \mu \mathrm { m } }$

Wt\%

O:38.2

Ca:41.6

Si:13.5

Al: 1.3

$\mathrm{Mg}: 5.4$

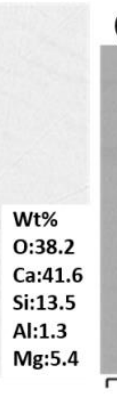

(b2)

-
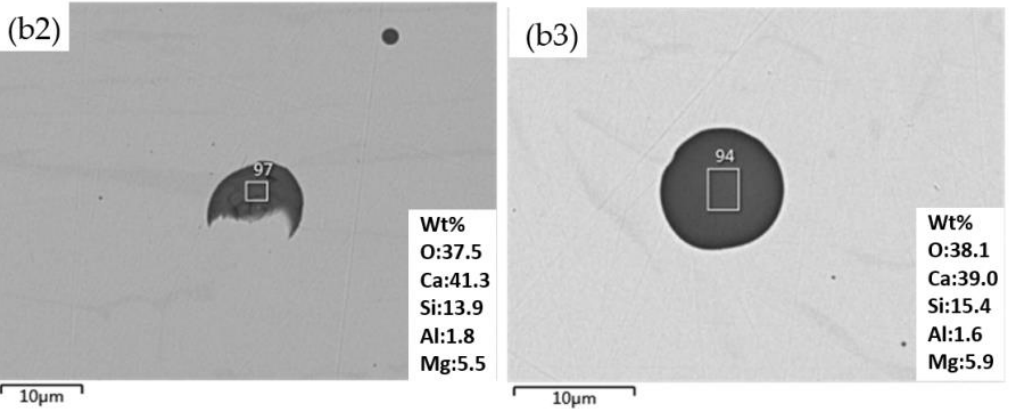

(c1)

(c2)

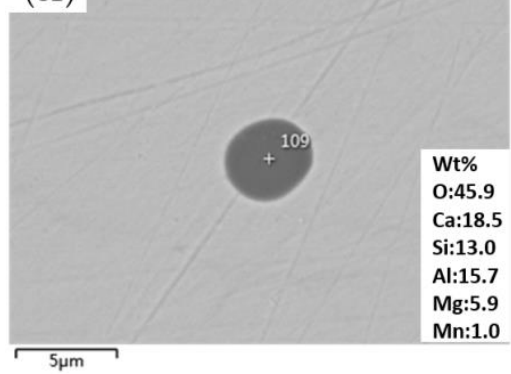

(c3)

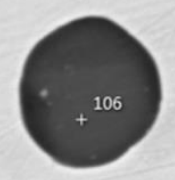

Wt\%

0:46.8

Ca:21.1

Si:13.5

Al:13.4

Mg:5.2

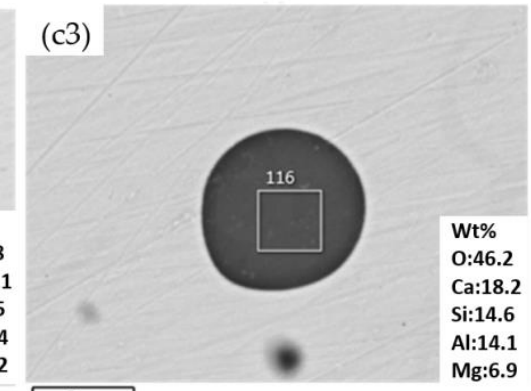

Figure 1. Morphology and composition of typical inclusions in samples: (a) typical inclusions at the end of AOD; (b) typical inclusions at the end of LF refining; (c) typical inclusions in the tundish.
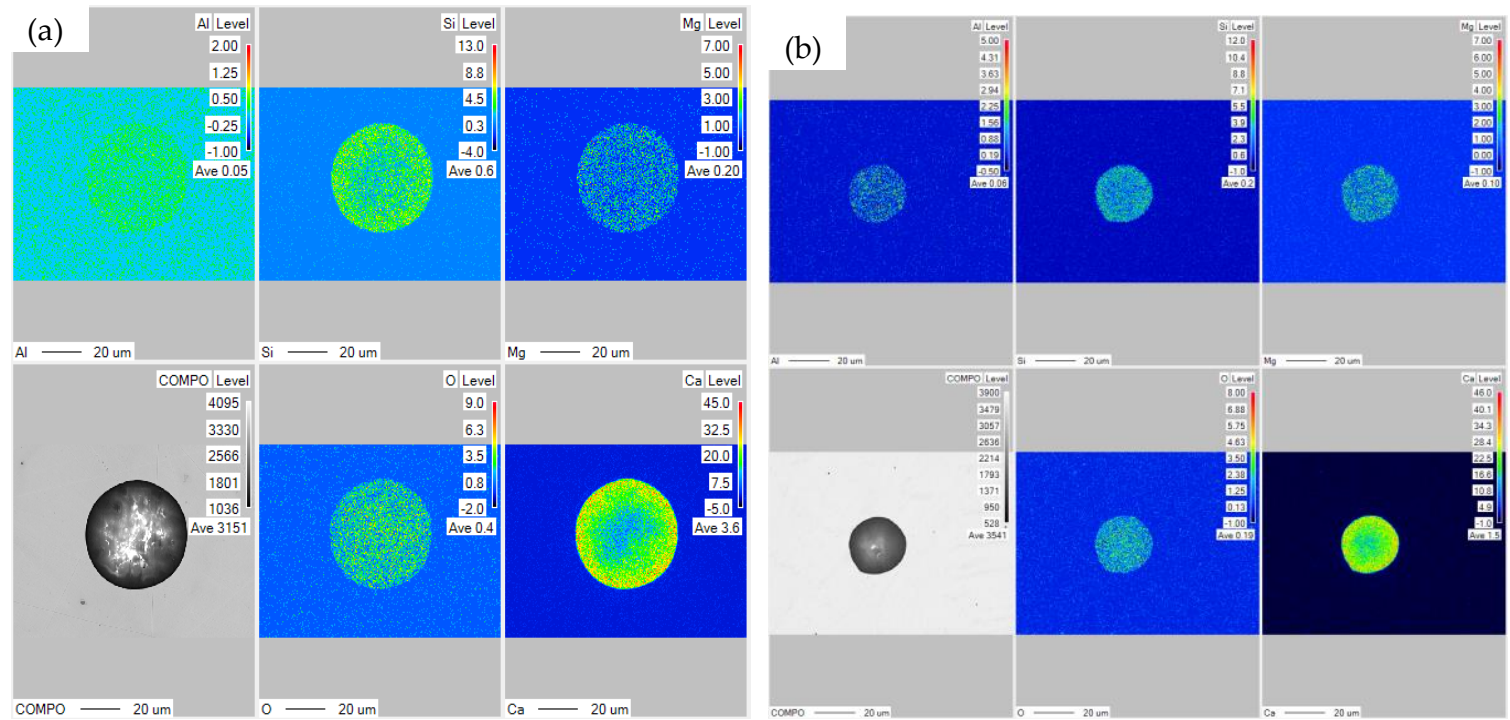

Figure 2. Cont. 

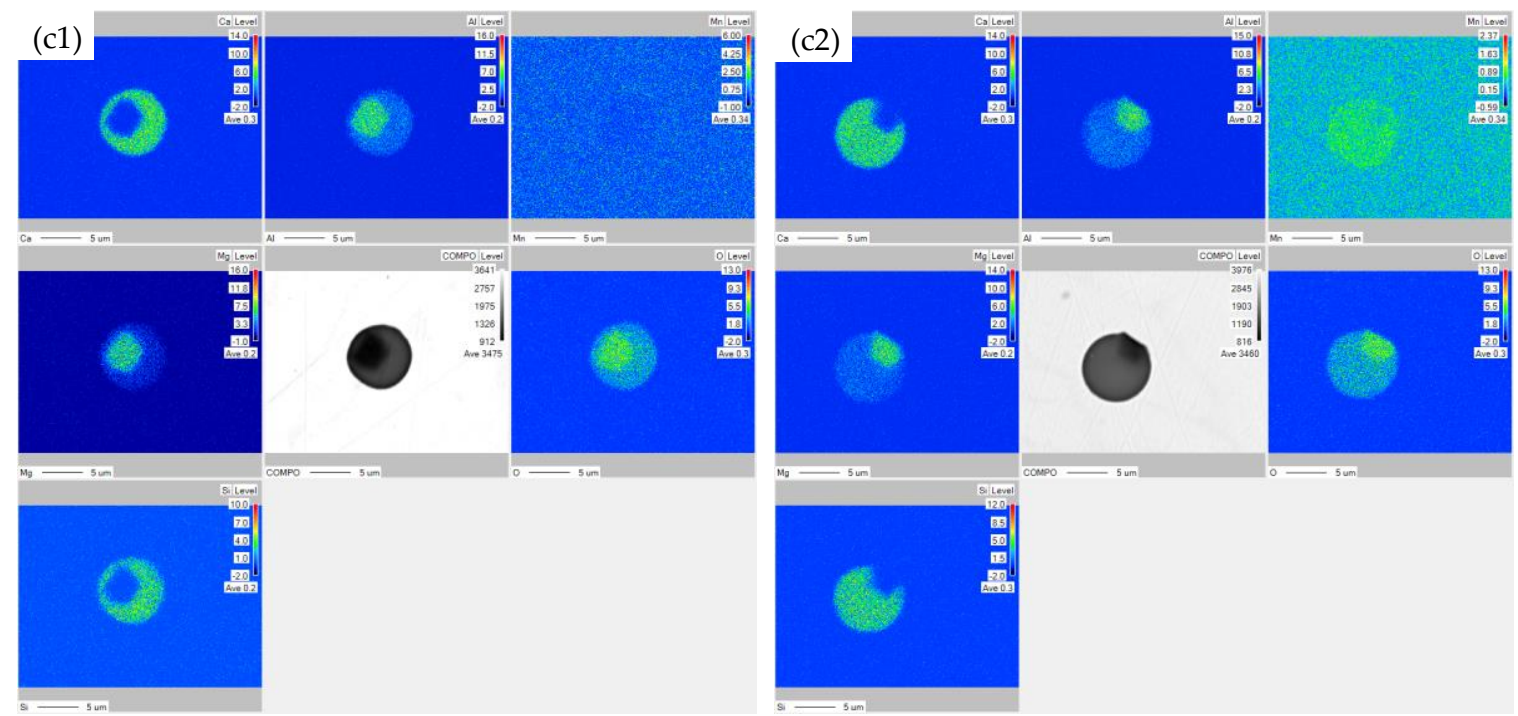

Figure 2. The WDS element maps of typical inclusions in samples: (a) typical inclusions at the end of AOD; (b) typical inclusions at the end of LF refining; (c) typical inclusions in the tundish.

\subsection{Number Density and Size of Inclusions in the Smelting Process}

The variations of the number density and the size of inclusions during the AOD-LF-CC production process were determined and are shown in Figure 3. Small inclusions $(\leq 10 \mu \mathrm{m})$ were dominant in all the samples. Larger inclusions $(\geq 10 \mu \mathrm{m})$ decreased in number density during the different stages of steelmaking. Large inclusions with a size larger than $20 \mu \mathrm{m}$ were present in liquid steel after AOD treatment, but were all adsorbed by the slag after LF refining, so there were no large inclusions from LF refining to the continuous casting tundish. Most inclusions were smaller than $10 \mu \mathrm{m}$ at each stage, and their number density decreased throughout the process.

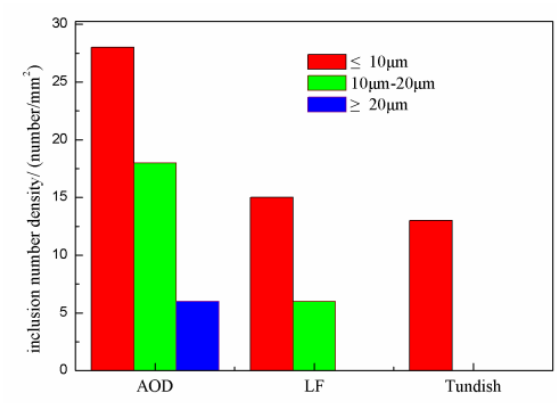

Figure 3. Size distribution of inclusions at different sampling locations.

\subsection{The Composition of Inclusions}

The composition of inclusions in the 304L stainless steel in the AOD-LF-CC process was determined and is shown in Figure 4. The composition of inclusions was mainly $\mathrm{CaO}-\mathrm{SiO}_{2}$, with a small amount of $\mathrm{Al}_{2} \mathrm{O}_{3}$ and $\mathrm{MgO}$ in the AOD stage. The basicity and $\left(\mathrm{Al}_{2} \mathrm{O}_{3}+\mathrm{MgO}\right)$ content of inclusions in LF were higher than for inclusions in AOD. In the tundish, there was a significantly higher content of $\left(\mathrm{Al}_{2} \mathrm{O}_{3}+\mathrm{MgO}\right)$ in inclusions than that at the LF refining stage. 


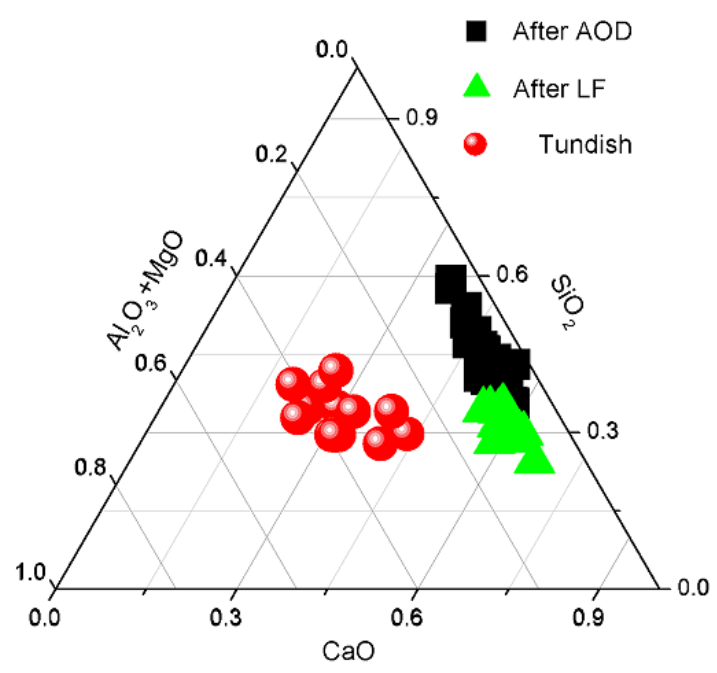

Figure 4. Composition distributions of inclusions (size larger than $5 \mu \mathrm{m}$ ) at the different stages.

\section{Discussion}

\subsection{Oxide-Inclusion Evolution in the Steelmaking Process}

To determine the characteristics of the inclusions of the AOD and LF stages, the compositions of inclusions in steel specimens were converted into the mass percentages of $\mathrm{CaO}, \mathrm{SiO}_{2}, \mathrm{MgO}$, and $\mathrm{Al}_{2} \mathrm{O}_{3}$, and then were plotted using $\mathrm{CaO}-\mathrm{SiO}_{2}-\mathrm{Al}_{2} \mathrm{O}_{3}$ ternary system phase diagrams, as shown in Figures 5 and 6 . The phase diagram of the $\mathrm{CaO}-\mathrm{SiO}_{2}-\mathrm{Al}_{2} \mathrm{O}_{3}$ system at $1873 \mathrm{~K}$ was calculated using FactSage 6.3 (Thermfact/CRCT \& GTT-Technologies, Aachen, Germany) software. It can be clearly seen that the composition of the inclusions was in good agreement with the slag composition. The inclusions are mostly made up of slag components, resulting from slag entrapment. During the cooling process, additional inclusions were formed, such as $\mathrm{CaSiO}_{3}$, containing a higher content of $\mathrm{SiO}_{2}$, and $\mathrm{Ca}_{2} \mathrm{SiO}_{4}$, containing a higher content of $\mathrm{CaO}$ precipitate. In addition, the $\mathrm{Al}_{2} \mathrm{O}_{3}$ content, $\mathrm{MgO}$ content, and the basicity of the LF slag were higher than those in AOD. Additionally, the $\mathrm{Al}_{2} \mathrm{O}_{3}$ content, $\mathrm{MgO}$ content, and the basicity of inclusions in LF were also higher than those in AOD, which is generally consistent with the change of slag composition. Overall, most inclusions during the AOD process were $\mathrm{CaSiO}_{3}$ with a high $\mathrm{SiO}_{2}$ content, and most inclusions during $\mathrm{LF}$ were $\mathrm{Ca}_{2} \mathrm{SiO}_{4}$, with a high $\mathrm{CaO}$ content. At the same time, the amounts of $\mathrm{Al}_{2} \mathrm{O}_{3}$ and $\mathrm{MgO}$ in inclusions in the AOD and LF stages were lower, similar to those in the slag. Therefore, it can be concluded that the inclusions formed in 304L stainless steel during the AOD and LF processes are mainly derived from the entrapment of the top slag. The strong argon stirring during AOD smelting and LF refining eventually allows inclusions to eventually reach equilibrium after action between the molten steel and slag. Thus, effective control of inclusions can be achieved by the careful control of the slag composition. The content of $\mathrm{MgO}$ in the slag in LF is higher than that in AOD (an increase from 4.5\% to 6\%), suggesting that slag and molten steel corrode the lining in the LF refining process. The erosion from the molten steel is more obvious, and results in a significant increase in the content of $\mathrm{MgO}$ in inclusions, so a key control strategy will be to inhibit the erosion of the lining during the refining process. It is worth noting that the $\mathrm{Al}$ content comes from the ferrosilicon present in the reaction, so lowering the $\mathrm{Al}$ content in the ferrosilicon will limit the formation of $\mathrm{Al}_{2} \mathrm{O}_{3}$ inclusions. 


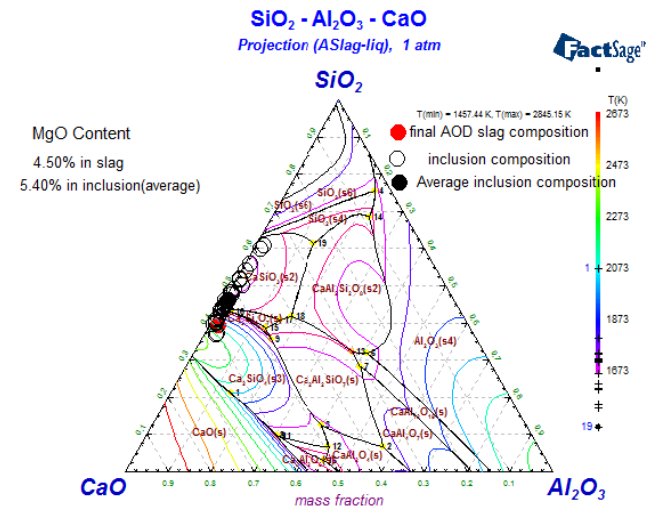

Figure 5. Chemical composition of inclusions and slag at the final stage of the AOD process.

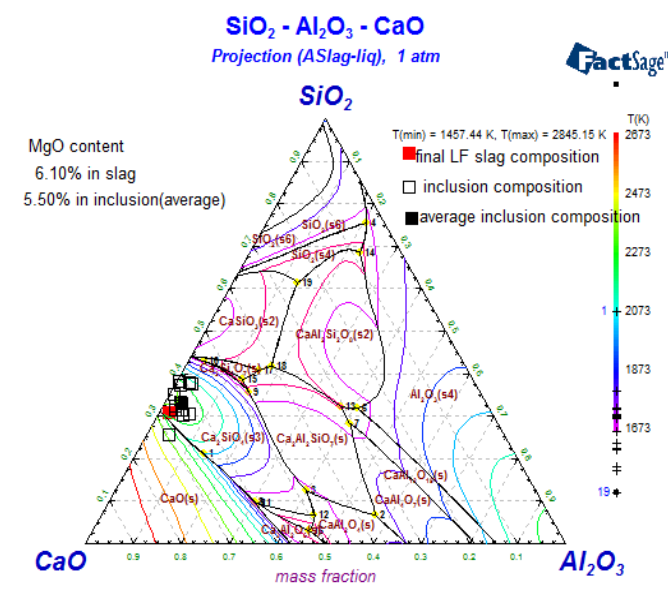

Figure 6. Chemical composition of inclusions and slag at the final stage of the LF process.

To elucidate the characteristics of the inclusions of the tundish, the compositions of the analyzed were converted into mass percentages of $\mathrm{CaO}, \mathrm{SiO}_{2}, \mathrm{MgO}$ and $\mathrm{Al}_{2} \mathrm{O}_{3}$ and were plotted on $\mathrm{CaO}-\mathrm{SiO}_{2}-\mathrm{Al}_{2} \mathrm{O}_{3}$ and $\mathrm{CaO}-\mathrm{Al}_{2} \mathrm{O}_{3}-\mathrm{MgO}$ ternary system phase diagrams, as shown in Figures 7 and 8 . As above, the phase diagrams of the $\mathrm{CaO}-\mathrm{SiO}_{2}-\mathrm{Al}_{2} \mathrm{O}_{3}$ and $\mathrm{CaO}-\mathrm{Al}_{2} \mathrm{O}_{3}-\mathrm{MgO}$ systems at $1873 \mathrm{~K}$ were calculated using the FactSage6.3 software. The content of $\mathrm{Al}_{2} \mathrm{O}_{3}$ increased significantly in the tundish, showing obvious deviation from the composition of the slag at the end of LF. In the tundish, due to the decreased temperature, inclusions contained the $\mathrm{Ca}_{2} \mathrm{Al}_{2} \mathrm{SiO}_{7}$ and $\mathrm{MgAl}_{2} \mathrm{O}_{4}$ spinel phase with a high content of $\mathrm{Al}_{2} \mathrm{O}_{3}$ precipitate, so the content of $\mathrm{Al}_{2} \mathrm{O}_{3}$ increased significantly [21].

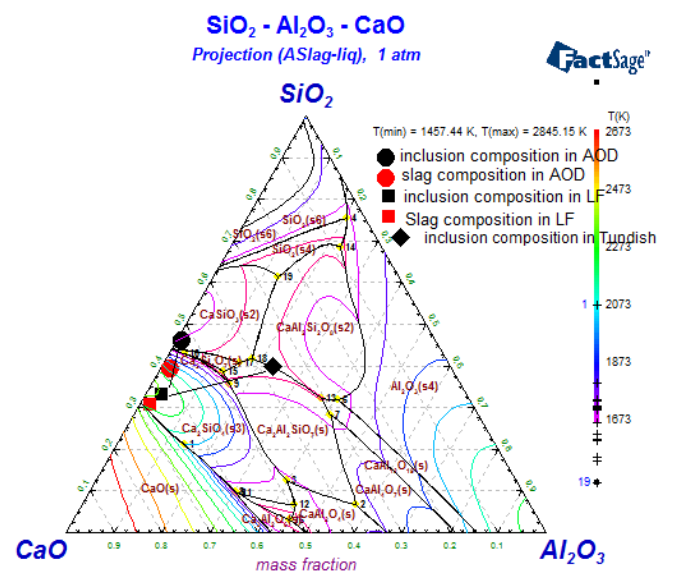

Figure 7. Chemical composition of the inclusions during the AOD-LF-CC process. 


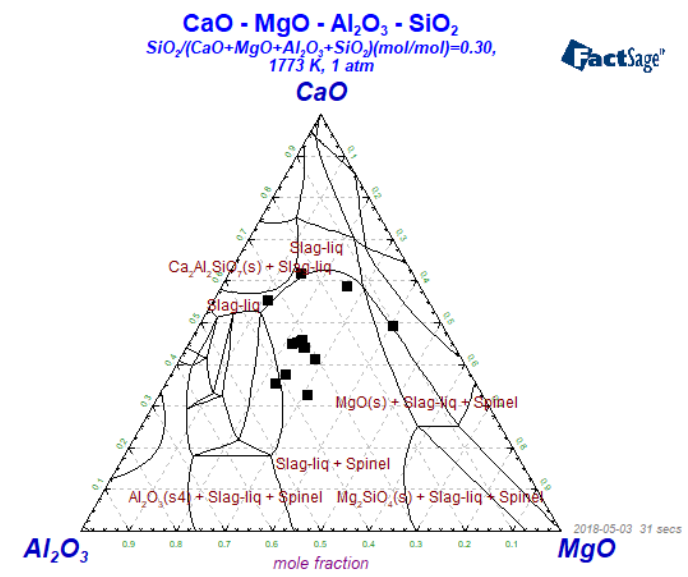

Figure 8. Chemical composition of inclusions in the tundish.

\subsection{The Effect of Slag on the $A l_{s}$ and $M g$ Content in Steel during the AOD-LF Process}

It can be seen from the above results that the levels of $\mathrm{Al}_{2} \mathrm{O}_{3}$ and $\mathrm{MgO}$ in the LF slag were higher than those in the AOD, and the levels of $\mathrm{Al}$ and $\mathrm{Mg}$ in the LF were also higher than those in the AOD. The $\mathrm{MgO}$ content in the slag is derived from refractory material according to reaction (1), and the $\mathrm{Mg}$ content in the steel originates from slag and refractory material, according to reactions (2)-(3). The $\mathrm{Al}$ content in steel comes from the ferrosilicon, and the increase in the $\mathrm{Al}$ content during refining results from an increase in slag basicity. The effect of slag on the $\mathrm{Al}_{\mathrm{S}}$ and $\mathrm{Mg}$ content in steel during the AOD-LF process was calculated using the Factsage 6.3 software. The FTmisc and FToxid databases were used, and the calculation module was equilibrated with $100 \mathrm{~g}$ of molten steel. Figure 9 shows the effect of the slag on the $\mathrm{Al}_{\mathrm{S}}$ content when the temperature varied from $1550{ }^{\circ} \mathrm{C}$ to $1650{ }^{\circ} \mathrm{C}$. $\mathrm{The}^{\mathrm{Al}} \mathrm{s}$ content in steel increased from AOD to LF at the same temperature. After the LF stage, the $\mathrm{Al}_{\mathrm{S}}$ content increased as the temperature decreased. Figure 10 shows the effect of the slag on the Mg content in steel when the temperature varied from $1550{ }^{\circ} \mathrm{C}$ to $1650^{\circ} \mathrm{C}$. The $\mathrm{Mg}$ content in the steel also increased from AOD to LF at the same temperature. During the AOD-LF process, the Mg content decreased as the temperature decreased.

$$
\begin{gathered}
\mathrm{MgO}_{\text {refractory }}=\mathrm{MgO}_{\text {slag }} \\
3(\mathrm{MgO})_{\text {slag }}+2 \mathrm{Al}=\left(\mathrm{Al}_{2} \mathrm{O}_{3}\right)_{\text {slag }}+3 \mathrm{Mg} \\
3 \mathrm{MgO}_{\text {refractory }}+2 \mathrm{Al}=\left(\mathrm{Al}_{2} \mathrm{O}_{3}\right)_{\text {slag }}+3 \mathrm{Mg}
\end{gathered}
$$

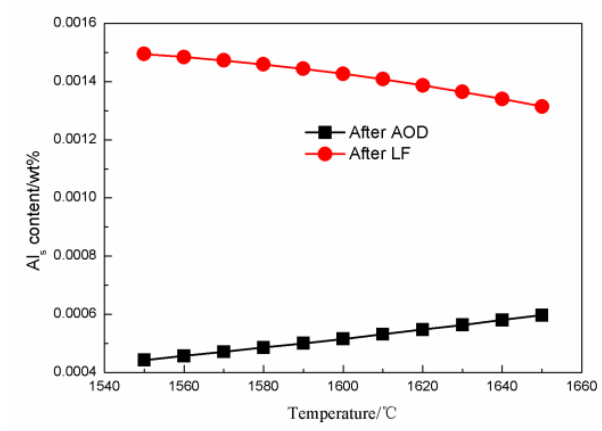

Figure 9. Effect of the slag on the content of $\mathrm{Al}_{\mathrm{S}}$ in steel. 


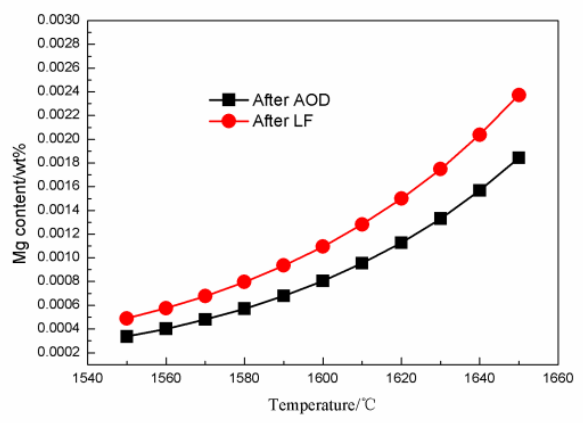

Figure 10. Effect of the slag on the content of $\mathrm{Mg}$ in steel.

\subsection{The Effect of Temperature on the Inclusion Contents in the Tundish}

It can be seen from the above analysis that the compositions of the inclusions present in the continuous casting tundish are quite different from those present after LF refining. No external elements were added to the molten steel from the end of LF refining to the continuous casting process, so it can be concluded that the reduction of temperature plays a leading role in the composition change of inclusions. Figure 11 shows the influence of temperature on the equilibrium composition of liquid inclusions as calculated by the Factsage 6.3 software. The FTmisc and FToxid databases were used, and the calculation module was equilibrated with $100 \mathrm{~g}$ of molten steel. With the decrease of temperature from the end of LF refining to continuous casting, the content of $\mathrm{Al}_{2} \mathrm{O}_{3}$ in the inclusion increased rapidly, while the content of $\mathrm{CaO}, \mathrm{SiO}_{2}$, and $\mathrm{MgO}$ decreased, but the content of $\mathrm{MnO}$ increased slightly. The rapid increase of the amount of $\mathrm{Al}_{2} \mathrm{O}_{3}$ in the $\mathrm{CaO}-\mathrm{SiO}_{2}-\mathrm{Al}_{2} \mathrm{O}_{3}-\mathrm{MgO}$ inclusions provides favorable conditions for the precipitation of the $\mathrm{MgO} \cdot \mathrm{Al}_{2} \mathrm{O}_{3}$ spinel phase in the continuous casting tundish.

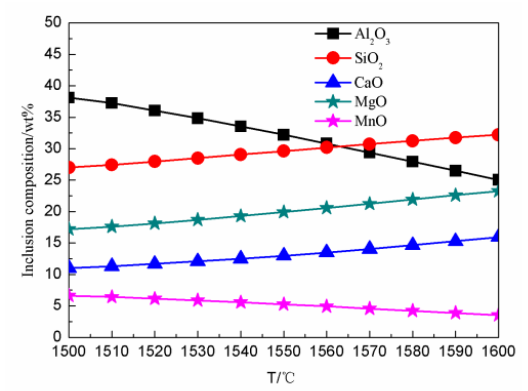

Figure 11. Effect of temperature on the inclusion composition.

The above results and analysis were used to describe the evolution of the inclusions and the formation mechanism of the inclusions during the smelting process of 304L stainless steel, as shown in Figure 12. There are two main types of inclusions: $\mathrm{CaO}-\mathrm{SiO}_{2}-\mathrm{Al}_{2} \mathrm{O}_{3}-\mathrm{MgO}-\mathrm{MnO}$ and $\mathrm{CaO}-\mathrm{SiO}_{2}-\mathrm{Al}_{2} \mathrm{O}_{3}-\mathrm{MgO}$.

The $\mathrm{CaO}-\mathrm{SiO}_{2}-\mathrm{Al}_{2} \mathrm{O}_{3}-\mathrm{MgO}$ inclusions are mainly slag inclusions after AOD treatment and LF refining. During smelting, the size of the inclusions decreased, and the $\mathrm{Al}_{2} \mathrm{O}_{3}$ and $\mathrm{MgO}$ content of inclusions increased. The increase in the $\mathrm{Al}_{2} \mathrm{O}_{3}$ and $\mathrm{MgO}$ content in inclusions is attributed to enhanced formation of $\mathrm{Al}_{2} \mathrm{O}_{3}$ and $\mathrm{MgO}$ caused by the reaction between $\mathrm{Al}_{\mathrm{S}}, \mathrm{Mg}$, and $\mathrm{O}$. The content of $\mathrm{Al}_{2} \mathrm{O}_{3}$ increased rapidly as the temperature decreased from LF to the tundish of continuous casting, resulting in $\mathrm{MgO} \cdot \mathrm{Al}_{2} \mathrm{O}_{3}$ spinel precipitates. The reaction is shown in Equation (4).

$$
(\mathrm{MgO})_{\text {in inclusions }}+\left(\mathrm{Al}_{2} \mathrm{O}_{3}\right)_{\text {in inclusions }}=\left(\mathrm{MgO} \cdot \mathrm{Al}_{2} \mathrm{O}_{3}\right)_{\text {in inclusions }}
$$

Evolution of the $\mathrm{CaO}-\mathrm{SiO}_{2}-\mathrm{Al}_{2} \mathrm{O}_{3}-\mathrm{MgO}-\mathrm{MnO}$ inclusions is similar with the first inclusion. The $\mathrm{Mg}$ and $\mathrm{Al}$ content in steel increases from $\mathrm{AOD}$ to $\mathrm{LF}$, and the levels of $\mathrm{Al}_{2} \mathrm{O}_{3}$ and $\mathrm{MgO}$ of inclusions in LF are also higher than those in AOD. With the decrease of temperature, from the end of LF refining to 
continuous casting, the $\mathrm{MnO}$ content of inclusions increases slightly, and some $\mathrm{CaO}-\mathrm{SiO}_{2}-\mathrm{Al}_{2} \mathrm{O}_{3}-\mathrm{MgO}$ inclusions change into $\mathrm{CaO}-\mathrm{SiO}_{2}-\mathrm{Al}_{2} \mathrm{O}_{3}-\mathrm{MgO}-\mathrm{MnO}$ inclusions. These inclusions containing $\mathrm{MnO}$ mainly appear in the tundish. This is because the mass fraction of manganese in 304L stainless steel is high (about $1.60 \%$ ), and the binding ability of manganese with oxygen is lower than that of silicon, so inclusions containing $\mathrm{MnO}$ do not typically form during the AOD and LF refining processes. The appearance of $\mathrm{CaO}-\mathrm{SiO}_{2}-\mathrm{Al}_{2} \mathrm{O}_{3}-\mathrm{MgO}-\mathrm{MnO}$ spherical inclusions is mainly related to the decrease in temperature that occurs in the transition from LF to the tundish. The rapid increase of $\mathrm{Al}_{2} \mathrm{O}_{3}$ content in the $\mathrm{CaO}-\mathrm{SiO}_{2}-\mathrm{Al}_{2} \mathrm{O}_{3}-\mathrm{MgO}-\mathrm{MnO}$ inclusions provides favorable conditions for the precipitation of the $\mathrm{MgO} \cdot \mathrm{Al}_{2} \mathrm{O}_{3}$ spinel phase in the continuous casting tundish, resulting in $\mathrm{MgO} \cdot \mathrm{Al}_{2} \mathrm{O}_{3}$ spinel precipitates.

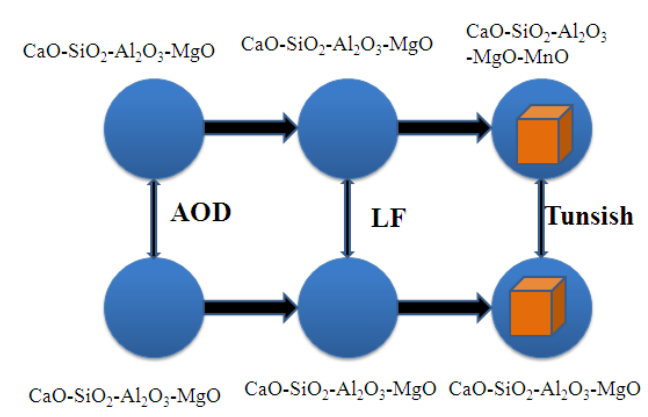

Figure 12. Schematic illustration of the formation mechanism of the inclusions containing spinel crystals during manufacturing of 304L stainless steel.

\section{Conclusions}

In this study, the inclusions formed in 304L stainless steel prepared for nuclear power applications using the EAF-AOD-LF-CC process were systematically investigated by microanalysis and thermodynamic analysis. The results were as follows:

1) The size of inclusions is mainly $\leq 10 \mu \mathrm{m}$ at various stages during the smelting process, and their number density is decreased in turn during the process of smelting.

2) The inclusions at the end of AOD and LF refining were very similar to the slag composition. The types of inclusions (size larger than $5 \mu \mathrm{m}$ ) were mainly $\mathrm{CaSiO}_{3}$ with high $\mathrm{SiO}_{2}$ content at the end of $\mathrm{AOD}$, and $\mathrm{Ca}_{2} \mathrm{SiO}_{4}$ with high $\mathrm{CaO}$ content at the end of $\mathrm{LF}$. The $\mathrm{Al}_{2} \mathrm{O}_{3}$ and $\mathrm{MgO}$ levels of inclusions increased from AOD to LF.

3) The $\mathrm{Al}_{\mathrm{s}}$ and $\mathrm{Mg}$ content in steel increased from $\mathrm{AOD}$ to LF refining, as calculated using FactSage6.3 software. The increased $\mathrm{Al}_{2} \mathrm{O}_{3}$ and $\mathrm{MgO}$ content in inclusions is attributed to increased formation of $\mathrm{Al}_{2} \mathrm{O}_{3}$ and $\mathrm{MgO}$ caused by the reaction between $\mathrm{Al}_{\mathrm{s}}, \mathrm{Mg}$ and $\mathrm{O}$.

4) In the tundish, the inclusions are mainly spherical $\mathrm{CaO}-\mathrm{SiO}_{2}-\mathrm{Al}_{2} \mathrm{O}_{3}-\mathrm{MgO}-\mathrm{MnO}$ and $\mathrm{CaO}-\mathrm{SiO}_{2}-\mathrm{Al}_{2} \mathrm{O}_{3}-\mathrm{MgO}$ with $\mathrm{MgO} \cdot \mathrm{Al}_{2} \mathrm{O}_{3}$ spinel precipitation. The content of $\mathrm{Al}_{2} \mathrm{O}_{3}$ in the inclusions increased rapidly with the decrease in temperature from the end of $\mathrm{LF}$ refining to continuous casting, as calculated using FactSage6.3 software. The rapid increase of $\mathrm{Al}_{2} \mathrm{O}_{3}$ in $\mathrm{CaO}-\mathrm{SiO}_{2}-\mathrm{Al}_{2} \mathrm{O}_{3}-\mathrm{MgO}$ inclusions provides favorable conditions for the precipitation of $\mathrm{MgO} \cdot \mathrm{Al}_{2} \mathrm{O}_{3}$ spinel in the continuous casting tundish.

Author Contributions: Conceptualization, G.C.; Methodology, X.C. and Y.H.; Software, J.L. and Y.H.; Validation, X.C., J.L. and Y.H.; Formal Analysis, X.C.; Investigation, X.C.; Resources, X.C.; Data Curation, X.C.; Writing-Original Draft Preparation, X.C.; Writing-Review \& Editing, Y.H.; Visualization, X.C.; Supervision, G.C.; Project Administration, X.C.

Funding: This research received no external funding.

Acknowledgments: The authors gratefully express their appreciation to the National Natural Science Foundation of China (Grant No. 51374020), the State Key Laboratory of Advanced Metallurgy at University of Science and Technology Beijing (USTB), and Jiuquan Iron and Steel Group Corporation for supporting this work.

Conflicts of Interest: The authors declare no conflict of interest. 


\section{References}

1. Momeni, A.; Abbasi, S.M. Repetitive thermomechanical processing towards ultra-fine grain structure in 301, 304 and 304L stainless steels. J. Mater. Sci. Technol. 2011, 27, 338-343. [CrossRef]

2. Zhao, R.; Zhang, Z.; Shi, J.-B.; Tao, L.; Song, S.-Z. Characterization of stress corrosion crack growth of 304 stainless steel by electrochemical noise and scanning kelvin probe. J. Cent. South Univ. T. 2010, 17, 13-18. [CrossRef]

3. Jiao, Z.; Hesterberg, J.; Was, G.S. Effect of post-irradiation annealing on the irradiated microstructure of neutron-irradiated 304L stainless steel. J. Nucl. Mater. 2018, 500, 220-234. [CrossRef]

4. Chikhi, N.; Fouquart, P.; Delacroix, J.; Piluso, P. Measurement of type 304L stainless steel and 16MND5 ferritic steel density and surface tension: possible impact for stratified molten pool. Nucl. Technol. 2019, 205, 200-212. [CrossRef]

5. Gupta, J.; Hure, J.; Tanguy, B.; Laffont, L.; Lafont, M.C.; Andrieu, E. Evaluation of stress corrosion cracking of irradiated 304L stainless steel in PWR environment using heavy ion irradiation. J. Nucl. Mater. 2016, 476, 82-92. [CrossRef]

6. Chandra, K.; Kain, V.; Raja, V.S.; Tewari, R.; Dey, G.K. Low temperature thermal ageing embrittlement of austenitic stainless steel welds and its electrochemical assessment. Corros. Sci. 2012, 54, 278-290. [CrossRef]

7. Garnier, J.; Bréchet, Y.; Delnondedieu, M.; Pokor, C.; Dubuisson, P.; Renault, A.; Averty, X.; Massoud, J.P. Irradiation creep of SA 304L and CW 316 stainless steels: Mechanical behaviour and microstructural aspects. Part i: Experimental results. J. Nucl. Mater. 2011, 413, 63-69. [CrossRef]

8. Yin, X.; Sun, Y.; Yang, Y.; Deng, X.; Barati, M.; McLean, A. Effect of alloy addition on inclusion evolution in stainless steels. Ironmak. Steelmak. 2017, 44, 152-158. [CrossRef]

9. Yoshioka, T.; Nakahata, K.; Kawamura, T.; Ohba, Y. Factors to determine inclusion compositions in molten steel during the secondary refining process of case-hardening steel. ISIJ Int. 2016, 56, 1973-1981. [CrossRef]

10. Kaushik, P.; Lehmann, J.; Nadif, M. State of the art in control of inclusions, their characterization, and future requirements. Metall. Mater. Trans. B 2012, 43, 710-725. [CrossRef]

11. Kaushik, P.; Pielet, H.; Yin, H. Inclusion characterisation - tool for measurement of steel cleanliness and process control: Part 1. Ironmak. Steelmak. 2009, 36, 561-571. [CrossRef]

12. Bi, Y.; Karasev, A.V.; Jönsson, P.G. Evolution of different inclusions during ladle treatment and continuous casting of stainless steel. ISIJ Int. 2013, 53, 2099-2109. [CrossRef]

13. Ehara, Y.; Yokoyama, S.; Kawakami, M. Formation mechanism of inclusions containing $\mathrm{MgO}-\mathrm{Al}_{2} \mathrm{O}_{3}$ spinel in type 304 stainless steel. Tetsu-to-Hagane 2007, 93, 208-214. [CrossRef]

14. Park, J.H. Thermodynamic investigation on the formation of inclusions containing $\mathrm{MgAl}_{2} \mathrm{O}_{4}$ spinel during 16Cr-14Ni austenitic stainless steel manufacturing processes. Mater. Sci. Eng. A 2008, 472, 43-51. [CrossRef]

15. Yin, X.; Sun, Y.H.; Yang, Y.D.; Bai, X.F.; Deng, X.X.; Barati, M.; McLean, A. Inclusion evolution during refining and continuous casting of 316L stainless steel. Ironmak. Steelmak. 2016, 43, 533-540. [CrossRef]

16. Choi, J.-Y.; Kim, S.-K.; Kang, Y.-B.; Lee, H.-G. Compositional evolution of oxide inclusions in austenitic stainless steel during continuous casting. Steel Res. Int. 2015, 86, 284-292. [CrossRef]

17. Park, J.H.; Todoroki, H. Control of $\mathrm{MgO} \cdot \mathrm{Al}_{2} \mathrm{O}_{3}$ spinel inclusions in stainless steels. ISIJ Int. 2010, 50, 1333-1346. [CrossRef]

18. Yan, P.; Huang, S.; Van dyck, J.; Guo, M.; Blanpain, B. Desulphurisation and inclusion behaviour of stainless steel refining by using $\mathrm{CaO}-\mathrm{Al}_{2} \mathrm{O}_{3}$ based slag at low sulphur levels. ISIJ Int. 2014, 54, 72-81. [CrossRef]

19. Ren, Y.; Zhang, L.; Fang, W.; Shao, S.; Yang, J.; Mao, W. Effect of slag composition on inclusions in Si-deoxidized 18Cr-8Ni stainless steels. Metall. Mater. Trans. B 2016, 47, 1024-1034. [CrossRef]

20. Sakata, K. Technology for production of austenite type clean stainless steel. ISIJ Int. 2006, 46, 1795-1799. [CrossRef]

21. Park, J.H. Formation mechanism of spinel-type inclusions in high-alloyed stainless steel melts. Metall. Mater. Trans. B 2007, 38, 657-663. [CrossRef]

(C) 2019 by the authors. Licensee MDPI, Basel, Switzerland. This article is an open access article distributed under the terms and conditions of the Creative Commons Attribution (CC BY) license (http:/ / creativecommons.org/licenses/by/4.0/). 